\title{
EVAluATING CANADA's NEW IMMIGRATION AND REFUGEE PROTECTION ACT IN ITS GLOBAL CONTEXT
}

\author{
CATHERINE DAUVERGNE*
}

The author examines the changes to Canadian Immigration Law in the new Immigration and Refugee Protection Act in a global context. She identifies three categories of changes: those that legislate current practice, those that are partial attempts to include legal recommendations, and those that are a direct response to globalization. The author concludes that overall, immigration law in Canada is resistant to substantial change, in spite of major efforts at public consultation. As a result, despite considerable changes in new legislation, the central features of the old legislation have remained intact.
L'auteur examine les changements apportés au droit canadien de l'immigration dans la nouvelle Loi sur l'immigration et la protection des réfugiés dans un contexte mondial. Elle a déterminé qu'il existe trois catégories de changements : ceux qui légiferent les pratiques actuelles, ceux qui visent en partie à inclure des recommandations juridiques et ceux qui réagissent directement à la mondialisation. L'auteur conclut que dans l'ensemble, le droit canadien de l'immigration résiste à des changements de taille malgré l'effort fait au niveau des consultations publiques. En conséquence, nonobstant les changements considérables qui ont été apportées à la nouvelle législation, les éléments centraux de l'ancienne législation sont demeurés intacts.

\section{TABLE OF CONTENTS}

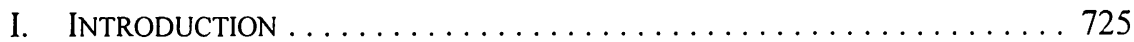

II. WHAT'S NEW IN THE IMMIGRATION

AND REFUGEE PROTECTION ACT .................... 726

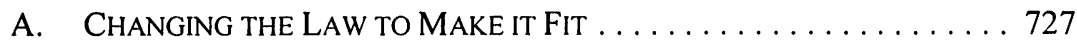

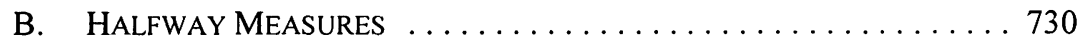

C. GlobalizIng CHANGES . . . . . . . . . . . . . . . . . . . 734

III. THE RESILIENCE OF IMMIGRATION LAW $\ldots \ldots \ldots \ldots \ldots \ldots \ldots \ldots \ldots$

IV. CONCLUSIONS: IMMIGRATION POLITICS AND ITS LAW $\ldots \ldots \ldots \ldots \ldots 742$

\section{INTRODUCTION}

On 28 June 2002, Canada's new Immigration and Refugee Protection Act ' came into effect. The IRPA and accompanying regulations, in total almost 300 pages of legislative effort, mark the culmination of close to a decade of public consultations about immigration law and policy ${ }^{2}$ and present a comprehensive overhaul of the previous legislation dating from

Canada Research Chair in Migration Law and Associate Professor, Faculty of Law, University of British Columbia. My thanks to the audience at the British Columbia Law Courts Inn Legal Studies Seminar in October 2002 where I delivered an earlier and abridged version of this article, and to Agnes Huang and Robert Russo for able research assistance.

S.C. 2001 , c. 27 [IRPA].

In 1994 consultations across the country were held which were later incorporated into the extended version of the 1995 Immigration Plan from Citizenship and Immigration Canada entitled Into the 21st Century: A Strategy for Immigration and Citizenship (Ottawa: Minister of Supply and Services, 1994) [Into the 21st Century] released in late 1994. These plans generated further public discussion, and were followed in late 1996 with the appointment of a three-member Legislative Review panel which reported in late 1997, Susan Davis, Roslyn Kunin \& Robert Trempe, Not Just Numbers: A Canadian Framework for Future Immigration (Ottawa: Minister of Public Works and Government Services Canada, 1997). Citizenship and Immigration Canada then conducted further consultations about the recommendations, 
the mid-1970s. ${ }^{3}$ Given the gargantuan effort that it represents and the new - but less brave - world into which it emerges, one of the most surprising things about the new IPRA is how little it changes. My argument here is that the IPRA is best understood and assessed in its global context. There are three elements to this argument. First, the principal new directions set out in the legislation are responses to the pressures of globalization. Second, the resilience of the basic structure of the IRPA is attributable to the role of immigration laws in liberal nations and to how nations fit into accounts of globalization. Third, Canadian public debate about immigration is anchored in a twentieth century perspective which a reflection on the dynamics of globalization illuminates. Each of these elements is important to evaluating the $I R P A$, to predicting how it will be interpreted, and to understanding contemporary Canadian politics of immigration that give vital content to the text of Canadian immigration law. I will address each element in turn before elaborating my conclusion that while the new IRPA responds in characteristic ways to contemporary globalizing forces, these legal developments are constrained by nostalgic politics.

\section{WHAT'S NEW IN THE IMMIGRATION AND REFUGEE PROTECTION ACT}

The IRPA undeniably contains a lot of changes, including new and significantly expanded objectives. ${ }^{4}$ It alters both the structure and procedure of the Immigration and Refugee Board (IRB),${ }^{5}$ defines family in a new way, ${ }^{6}$ alters the points system which provides the central logic for independent immigrant screening, ${ }^{7}$ and redefines skilled worker migration. It also provides a tighter framework for discretionary decision-making and for delegated legislating power, and it expands the jurisdiction of the Refugee Protection Division of the IRB. ${ }^{8}$ The IRPA curtails appeal rights ${ }^{9}$ and it brings more stringent measures in the areas of people

and issued a response in the form of a white paper entitled Building a Strong Foundation for the $21 \mathrm{st}$ Century: New Directions for Immigration and Refugee Policy and Legislation (Ottawa: Minister of Public Works and Government Services Canada, 1998). This became the basis for the bill to replace the former Immigration Act, R.S.C. 1985, c. I-2 (repealed), which was first tabled in early 2000 . The tabling led to further consultations and extensive public comment before the bill died as Parliament was dissolved in late 2000. After the government was returned, amended legislation in the form of the IRPA was introduced and passed in November 2001. The process of developing regulations to accompany the new law involved another round of consultation and corresponding attention, prior to the IRPA taking effect in June 2002.

Immigration Act, ibid. passed in 1976, came into effect in 1978. It was repealed and replaced by the IRPA in 2001.

Supra note 1, s. 3.

Ibid., ss. 151-86. The key changes here are on the refugee side, where the jurisdiction of the board is increased and a new division is written into the law.

The most significant change in family definition is a reframing of the partnership relationship which is at the core of the legislation's definition of family (Immigration and Refugee Protection Regulations, S.O.R./2002-227, ss. 1-2 [IRPR]).

Ibid., ss. 73-115.

Ibid., s. 97. The Refugee Protection Division is the new name under IRPA for the former Convention Refugee Determination Division. The Immigration Division is the new name for the former Adjudication Division. These changes make the titles both more straightforward and accessible, but nothing else is affected by them.

Ibid., s. 64. This removes the right to a merits appeal before the IRB for those who are found inadmissible on grounds of security, human rights violations, or serious or organized criminality. 
smuggling, ${ }^{10}$ people trafficking, ${ }^{11}$ and criminal inadmissibility. ${ }^{12}$ It is too soon to say which change will have the most impact. In my view, however, we can begin to predict the answer by considering that the changes ushered in by the new IRPA can be roughly grouped into three categories: those that provide a legal framework for previous practice, those that go part way towards full-scale change and those that mark the law as belonging to a global era.

\section{A. Changing the LaW to Make it Fit}

The first of these groups may be the largest. A large number of the most eye-catching changes in the IRPA simply have the effect of bringing the letter of the law in line with trends in bureaucratic practice under previous discretionary provisions. These changes are significant for what they reveal about the place of discretion in immigration decision-making. Though the changes will be fruitful areas for future comparative analysis of the differences between discretionary and legal decision-making, they will not profoundly alter the answer to the vital immigration question, "who gets in"?

Alterations to the definition of family are a principal example here. The new conjugal, common law and marriage partnership formulation removes formal discriminatory preferences for married heterosexual families. ${ }^{13}$ This is in itself a significant and overdue statement for Canadian immigration law. Prior to this, however, the practice for many years was to allow same-sex partners of Canadian residents or citizens to attain permanent residency in Canada on the basis of a "humanitarian and compassionate" exception to the law. ${ }^{14}$ It is reasonably possible that under the new legal provisions same-sex partners could be subject to more stringent scrutiny, as the test is now whether their relationship complies with the law, rather than whether an exception will be made to accommodate it. The new tripartite partnership recognition formula will undoubtedly lead to unintended innovations, as the categories are potentially overlapping and the definitions have yet to be judicially interpreted. ${ }^{15}$ Variations and challenges of this sort, however, are beyond the intention of the

$11 \quad$ Ibid., s. 117.

$11 \quad$ Ibid., s. 118.

12 Ibid., ss. 33-37.

13. IRPR, supra note 6. In ss. 1-2, a common law partner for the purposes of family class sponsorship is defined as "an individual who is cohabiting with the person in a conjugal relationship, having so cohabited for a period of at least one year" and a conjugal partner is defined as "a foreign national residing outside Canada who is in a conjugal relationship with the sponsor and has been in that relationship for a period of at least one year." A conjugal relationship is not defined.

14 This was possible under former Regulation 2.1 and the Immigration Act, supra note 2, s. 114(2) which stated:

The Governor in Council may, by regulation, authorize the Minister to exempt any person from any regulation made under subsection(1) or otherwise facilitate the admission of any person where the Minister is satisfied that the person should be exempted from that regulation or that person's admission should be facilitated owing to the existence of compassionate or humanitarian consideration.

is It is also notable that the former category of "fiancé" has been removed. This category accounted for approximately 14,000 applications between 1996 and 2001 and was highly gendered (between 75 percent and 82 percent of visas over the past six years were given to women) (see Citizenship and Immigration Canada, Facts and Figures: Immigration Overview 1998 (Ottawa: Minister of Public Works and Government Services Canada, 1998), online: Citizenship and Immigration Canada $<w w w$. cic.gc.ca/english/pdf/pub/facts 1998.pdf>). See also Facts and Figures: Immigration Overview 2001 (Ottawa: Minister of Public Works and Government Services Canada, 2001), online: Citizenship and 
government in reframing the legislation, which was plainly to remove discrimination and to end a completely discretionary program for same-sex partners. ${ }^{16}$ It will be important, from here on, to track whether this change in the symbolic power of the law equates to any change at all in outcomes for individuals.

Other changes under the family migration heading also serve to bring the law into line with well established exceptions to it. Partners and children are no longer made inadmissible on the basis of potential "excessive demand" for medical services. ${ }^{17}$ This alteration will considerably reduce the importance of a contorted line of case law establishing how excessive demand was to be assessed, ${ }^{18}$ and will reduce pressure on the IRB to assess sponsorship rejections on this basis under its "equitable jurisdiction" which mirrors the executive's discretionary humanitarian and compassionate powers. ${ }^{19}$ The age cutoff for children to qualify as "dependent" and thus eligible as family class members has been raised from 19 to $22 .{ }^{20} \mathrm{~A}$ new subgroup within the family class has also been introduced allowing partners to apply for permanent residency without leaving the country. ${ }^{21}$ Each of these changes also moves the law in the same direction as previous discretionary practices and pressures.

A series of changes to refugee determination by the IRB can also be categorized as the law following evolving practice. Under the IRPA it is now the norm that refugee determinations will be made by one member of the tribunal sitting alone ${ }^{22}$ with the option of constituting multiple-member panels to consider particular matters. ${ }^{23}$ This replaces the previous twomember panel regime where only one member needed to find in favour of an applicant for refugee status to be awarded. In practice, two-member panels had become rare by 2002 when the old provisions were replaced. Instead, refugee determinations were usually made by a member sitting alone, with the consent of the applicant to do so. Evidence that members rarely disagreed with each other, and that applicants rarely denied consent for the single member formula made this change a "logical" one, bringing the law into line with established

Immigration Canada $<w w w . c i c . g c . c a / e n g l i s h / p d f / p u b / f a c t s 2001 . p d f>$. Presumably, those who used this visa in the past can now fit within the category of "conjugal" partners, see supra note 13 and accompanying text. This alteration also reflects changing Canadian values and social practices. The government's Regulatory Impact Analysis Statement, C. Gaz. 2002.II.254 at 254 states that these changes aim to take into account "current social realities" and, at 178, to make the IRPA consistent with the Modernization of Benefits and Obligations Act.

17 IRPR, supra note 6, s. 24.

18 Examples include: Ahir v. Canada (Minister of Employment and Immigration), [1984] I F.C. 1098 (F.C.A.); Jiwanpuri v. Canada (Minister of Employment and Immigration) (1990), 109 N.R. 293 (F.C.A.); and Deol v. Canada (Minister of Employment and Immigration) (1992), 145 N.R. 156 (F.C.A.).

1.) Section 67(1)(c) of the new legislation provides that the Immigration Appeal Division may allow an appeal on the basis that "other than in the case of an appeal by the Minister, taking into account the best interests of a child directly affected by the decision, sufficient humanitarian and compassionate considerations warrant special relief in light of all the circumstances of the case." A similar provision existed in the Immigration Act, without reference to the best interests of children concerned.

Supra note 6, s. 2.

Ibid., ss. 123-29.

IRPA, supra note 1, s. 163.

Section 163 of the IRPA also provides that the Chairperson may constitute a panel of three members in any Division except the Immigration Division, with no constraints on when the Chairperson may do so. 
practice. It is important to consider that this denies a layer of protection to claimants and that there were no safeguards on the process of eliciting consent; however, these factors do not alter the symmetry between the new formality and the earlier informality.

It is similarly true that the expanded jurisdiction of the Refugee Protection Division to consider protection issues beyond the definition of refugee merely relocates this assessment and therefore also can be considered a change promoting efficiency. The new jurisdiction requires the Tribunal to consider if returning an individual to their place of origin would infringe Canada's commitments under the United Nations Convention Against Torture. ${ }^{24}$ It also provides a way of protecting individuals who do not come within the letter of international law, either in the United Nations Convention Relating to the Status of Refugees $^{25}$ or the Torture Convention. While this is a significant change for Tribunal members, ${ }^{26}$ those determined not to be refugees who were nonetheless faced with serious protection issues previously did have ways to bring these concerns to Canadian decisionmakers and to be granted permission to remain in Canada. As was the case in family class exceptions, this was often done under the rubric of humanitarian and compassionate discretion.

Changes in this category are significant with regard to the placement of discretionary power. Immigration law is traditionally marked by a high degree of discretion, traceable to its close relationship with core executive power. ${ }^{27}$ It appears at first blush that one effect of the IRPA is to reduce the scope of discretion significantly. Such an outcome is unlikely, however, for reasons I discuss in the next section. Given this, it is important to find other reasons for these changes. There are two possible explanations, each of which supports the conclusion that the massive law reform effort of the IRPA is in large measure aimed at reinforcing the status-quo. First, it is a good housekeeping measure to bring the law in line with practice, even in an arena dominated by discretion. This provides protection for executive decision-making from potential challenge and bolsters support for and from a rule of law ideology, with very little effort. Second, bringing the law in line with well-established exceptions, especially following extensive public consultations, means that the law is meeting

$24 \quad$ United Nations Convention Against Torture, 4 February 1985, 1673 U.N.T.S. 425 [Torture Convention]. Signed by Canada on 23 August 1985 and ratified on 24 June 1987. Article 3 of the Convention states that "[n]o State Party shall expel, return ("refouler") or extradite a person to another State where there are substantial grounds for believing that he would be in danger of being subjected to torture."

25 United Nations Convention Relating to the Status of Refugees, 189 U.N.T.S. 150 [Refugee Convention], entered into force April 22, 1951, states that "[ $n$ ]o Contracting State shall expel or return ("refouler") a refugee in any manner whatsoever to the frontiers of territories where his life or freedom would be threatened on account of his race, religion, nationality, membership of a particular social group or political opinion."

26 In the first four months of 2003, the Refugee Protection Division accepted 5399 claims. Only 1 percent of these were accepted on the basis of protection other than refugee protection under s. 97 of the IRPA. An additional 1 percent were accepted on the basis of qualifying for refugee protection and non-refugee protection. These statistics were supplied by the IRB Documentation Centre in Vancouver and are on file with the author.

27 This argument is at the core of Stephen Legomsky's Immigration and the Judiciary: Law and Politics in Britain and America (Oxford: Oxford University Press, 1987). His study of immigration law in Britain and the United States is equally applicable to Canada and Australia. Sean Brawley makes a similar point in The White Peril: Foreign Relations and Asian Immigration to Australasia and North America 1919-1978 (Sydney: University of New South Wales Press, 1995). 
the needs of both the government and key stakeholders. It reflects the fact that a massive number of these types of exceptions had been both sought and granted over the past two decades. This is not an innovative or idealistic path to law reform, but it does ensure both the functioning of the law and the support of those who engage it on a day-to-day basis.

The executive and judicial application of these aspects of the new IRPA will provide a fascinating proving ground for the interaction of legal and discretionary decision-making. Key questions to ask will be whether scrutiny of individuals is increased under legal provisions and whether a similar rate of permissions is granted. These provisions will also provide a way to track the evolving meaning of humanitarianism in Canadian domestic law. We will now be able to analyze how humanitarian exceptions initiated to offer compassion the law denied will take shape once given official status. As discretion in immigration law is almost always re-labelled as either "humanitarian and compassionate" or "in the national interest," meanings can be discerned by puzzling out how these forms are given substance. ${ }^{28}$

\section{B. Halfway Measures}

A second group of changes contained in the IRPA can best be read as falling short of calls for a thorough reorientation of Canadian immigration law. Unlike the first group, these changes do not simply codify past practice, and to that extent are genuinely something new in the law. However, when considered against the calls for reform they appear to address, they are at best halfway measures. As such, the crucial question for assessment is whether these changes bring anything to the legislation or whether they exacerbate the problems they are aimed at remedying by stopping short of the direction called for.

Of the various reform proposals circulated in the decade leading to the implementation of the IRPA, the most important is the 1997 Legislative Review, Not Just Numbers: A Canadian Framework for Future Immigration. ${ }^{29}$ This is so because each of the other documents was either authored directly by the Canadian government or generated in response to government proposals. ${ }^{30}$ The Legislative Review was convened and supported by a Secretariat within the Department of Citizenship and Immigration, but was designed to operate at arms length to it in proposing new legislation for the immigration and refugee areas. ${ }^{31}$ The success of the Review team ${ }^{32}$ in establishing this distance is reflected in the facts that their report prompted

I have previously written about humanitarian discretion in "Amorality and Humanitarianism in Immigration Law" (1999) 37 Osgoode Hall L.J. 597 [Dauvergne, "Amorality and Humanitarianism"]. Davis, Kunin \& Trempe, supra note 2.

Ibid.

Ibid. at Annex 1

Chaired by Robert Trempe, with Susan Davis and Roslyn Kunin as additional members. 
the government to embark upon another round of consultations almost immediately ${ }^{33}$ and that most of their proposals are not taken up in the new law. ${ }^{34}$

There were two overarching recommendations in the Legislative Review that exemplify the halfway measures approach of the eventual law. The first is the call for two acts rather than one. Arguing that the logic of immigration and that of refugee protection are distinct, the Review suggested that immigration concerns had more in common with questions of citizenship and recommended that new legislation should combine these two, while separating refugee concerns under a protection act. ${ }^{35}$ This proposal reflects a recognition that merging immigration politics with refugee concerns is damaging to both pursuits. In brief, this is because immigration in "new" nations like Canada has always been about serving the national interest and thus is closely intertwined with the politics of defining that interest. Refugee protection, on the other hand, is about international legal commitments and can be a temporary standard not necessarily involving settlement. ${ }^{36}$ The proposal also reflected the Review's concern with the multiple and contradictory objectives of the 1976 Immigration Act. $^{37}$

There is only one new IRPA. The new name, Immigration and Refugee Protection Act, seems to aver the concern about articulating and clarifying the impetus of the law. Rather than have two pieces of legislation, the new law has an immigration part and a refugee part, along with three other parts. Objectives for the first two parts are grouped in subsections of the IRPA, with some additional overall objectives added, so that the new legislation now has 25 separate "objectives" paragraphs. ${ }^{38}$ The result is even more multiple and contradictory objectives than the previous legislation. In one sense, there is an honest transparency about this type of legislative drafting. It acknowledges that there may be any number of reasons, even contradictory reasons, for prohibiting or permitting immigration or denying or granting protection. On the other hand, the purpose of this type of provision is to guide interpretation of the legislation and to shape discretionary decision-making within its ambit. ${ }^{39}$ The present

The Legislative Review team reported in late December 1997. By February 1998, the government was again on the public consultation trail which culminated in the white paper Building on a Strong Foundation for the 21st Century released in January 1999. In this report, specifically at page 5, the work of the Legislative Advisory group is recast as "a catalyst for debate" rather than the guide to "future legislative and policy adjustments" discussed in its terms of reference (see Davis, Kunin \& Trempe, supra note 2).

Their report did support most of the changes discussed in the previous section, but these did not represent the creative thrust of the report.

Davis, Kunin \& Trempe, supra note 2 at c. 2: "A New Legislative and Accountability Framework." The other legislation they proposed was an immigration and citizenship act. The decade-long debate which culminated in the IRPA has been accompanied by a less extensive debate about new citizenship legislation. A new Canadian Citizenship Act, Bill C-18, was tabled on 31 October 2002, and, as of June 2003 , is at the second reading stage before the House of Commons.

See James C. Hathaway, "Refugee Law is not Immigration Law" (2002) World Refugee Survey 38-45, online: U.S. Committee for Refugees $<$ www.refugees.org/downloads/wrs02/reflaw_wrs02.pdf $>$. See further, James C. Hathaway \& R. Alexander Neve, "Making International Refugee Law Relevant Again: A Proposal For Collectivized And Solution-Oriented Protection" (1997) 10 Harv. Hum. Rts. J. 115. Supra note 2 .

38 Supra note 1 at s. 3. These objectives are grouped under the subheadings "Immigration," "Refugees," and "Application." 
objectives are so complex that they can neither guide nor constrain. They serve no purpose other than to announce that the government is aware of how thorny an issue immigration is in Canadian politics and to ensure that the law is able to mirror prevailing political views without amendment.

The overlapping muddle of political views about immigration and refugee protection in Canada is precisely why it is difficult, if not impossible, to achieve a political consensus around the idea of creating two acts. While the logic of immigration and the logic of refugee protection may be separable, any government which does this loses its capacity to elide from refugee discourse to immigration discourse - and back - as the politics of the day demand. The IRPA's halfway-measures approach is politically and judicially freeing, while gesturing toward one of the central planks of the Legislative Review.

A second overarching recommendation of the Legislative Review was that discretionary decision-making should be curtailed, and in particular that entire programs proliferating under the former capacity for humanitarian and compassionate grounds be reigned in and framed by law. ${ }^{40}$ In some measure, this aspiration is taken up in the new legislation, as I discussed above. ${ }^{41} \mathrm{~A}$ standard regulation-making capacity is replaced with more detailed provisions allowing for regulations to accompany each part or division of the legislation. The broad provision for humanitarian and compassionate exceptions has been made somewhat more specific. ${ }^{42}$ In addition, there are 11 provisions that allow these exceptions to the legal requirements of particular parts or divisions of the IRPA. ${ }^{43}$

It is difficult to conclude that this amounts to a reduction in the capacity for discretionary decision-making. It is certainly the case now, while the legislation is new, that there are not entire programs flourishing under a generally-worded capacity to make exceptions. But there is nothing in the legislation to prevent such accretions, and everything in past practice indicates that discretionary decision-making will burgeon in an immigration law context. In addition to the opportunities for exceptions in the name of humanitarianism and compassion, there are a significant number of opportunities for exceptions on the grounds of national interest, an equally malleable term. ${ }^{44}$ Taken in sum, this shuffling of discretion can be no more than a halfway measure. As scant guidance can be drawn from the "objectives" of the $I R P A$, there is little reason for the courts to constrain discretionary decision-making and the task of giving meaning to the national interest and the nation's compassion is left in executive hands.

See Davis, Kunin \& Trempe, supra note 2 at c. 10, "Rethinking Discretion: Residual Powers."

See notes 14 to 20 above, and accompanying text.

IRPA, supra note 1 at $\mathrm{s}$. 25 , which provides:

The Minister shall, upon request of a foreign national who is inadmissible or who does not meet the requirements of this Act, and may, on the Minister's own initiative, examine the circumstances concerning the foreign national and may grant the foreign national permanent resident status or an exemption from any applicable criteria or obligation of this Act if the Minister is of the opinion that it is justified by humanitarian and compassionate considerations relating to them, taking into account the best interests of a child directly affected, or by public policy considerations.

The earlier formula is cited in full at supra note 14. 
A third reflection of the government's lack of commitment to change in the law is the ongoing "unimplemented" status of the Refugee Appeal Division. This addition to the IRB, adding a new Division to the existing three, was written into the IRPA. However, before the $I R P A$ came into force, the Minister announced a delay in implementing the Refugee Appeal Division ${ }^{45}$ and more than one year later has not indicated a date for its implementation. ${ }^{46}$ The new Division fit with the Legislative Review's call for increased fairness and transparency in the refugee process. While Canada's refugee determination system has generally been well-regarded internationally, most major Western refugee-receiving nations offer refugee claimants the possibility of a merits appeal of their claim. ${ }^{47}$ Claimants in Canada are only eligible to seek judicial review, and only then with leave of the Federal Court. ${ }^{48}$ When the former regime was functioning at its fullest, the argument that the Canadian system was world class and a merits review would have been almost redundant, was a reasonably easy argument to make. However, as the two-member system for determinations was removed in this round of law reform and legal aid has been pared back across the country, ${ }^{49}$ the overall fairness of the refugee process is seriously impinged by not providing a merits review. The Refugee Appeal Division is to be an in-house review on the papers, and is therefore the weakest possible merits review formula. Nonetheless, it is a principled start towards the Legislative Review's call to improve fairness and efficiency by streamlining protection procedures within one agency. To write it into the law and then not implement it is, perhaps, the ultimate in incomplete initiatives.

These halfway measures are, for the most part, examples of stasis - of instances where the resilience of the former legislation won out and the result is more like tinkering at the edges in a way that appears somewhat attentive to the legislative review. What is important to watch for in regard to changes of this type is whether a slight change is in fact any change at all, and whether it exacerbates rather than solves the issues that the Legislative Review Team was concerned about. There are plausible reasons to believe that the objectives of the

Citizenship and Immigration Canada, News Release, 2002/12, "Refugee Appeal Division Implementation Delayed" (29 April 2002), online: Citizenship and Immigration Canada <www.cic.gc. $\mathrm{ca} / \mathrm{english} / \mathrm{press} / 02 / 0212$-pre.html $>$.

This is evidenced by Minister Denis Coderre's responses to questions in the House of Commons and in correspondence with the Canadian Council for Refugees. In a 3 May 2003 address to the Canadian Bar Association, he stated: "When I delayed implementing the Refugee Appeal Division, I pointed to pressures on our program that we needed to resolve first. Those pressures are still present just as there are on-going safeguards in place to ensure claimants have fair consideration of their claims" (online: Citizenship and Immigration Canada <www.cic.gc.ca/english/press/speech/canadian-bar.html $>$ at 7 ). This is possible in the United Kingdom under the Nationality, Immigration and Asylum Act 2002, (U.K.), 2002, c. 41 , part 5; in the United States most decisions can be reviewed by the Board of Immigration Appeals (8 C.F.R., ch. 5, part 1003) or reconsidered by an immigration judge; in Australia merits review for refugee claimants is provided by the Refugee Review Tribunal (Migration Act 1958 Cth, Part 7); in Germany appeals may be taken to the Administrative Court, see "Legal Handbook for Refugees - A Practical Guide Through German Asylum and Alien Law," online: Pro Asyl <www. proasyl.de/index.html >; in France merit appeals are heard by the Refugee Appeals Commission, see

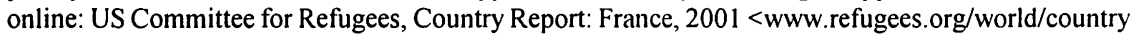
$\mathrm{rpt} /$ Europe/2001/france.htm>. IRPA, supra note 1 , ss. $72-75$.

4) Most recently, in May 2003, the Attorney General of British Columbia and the Legal Services Society of British Columbia have signed a Memorandum of Understanding stating that there will be no funding for immigration and refugee matters after 31 March 2004. This means that funding for new claimants will run out in the autumn of 2003 . 
legislation are less coherent, that discretionary decision-making will erupt under the new provisions, and that transparency and fairness in the refugee process have been diminished rather than enhanced. If this proves the case, these minimalist changes will begin to add up to something - but not what the Legislative Review team envisioned.

\section{Globalizing Changes}

The third group of changes in the IRPA marks it as a product of an era of globalization. These changes move in two directions: in the direction of "cracking down" on migration violations of various sorts, and in the opposite direction of making immigration for wellqualified economic migrants easier. The legislation does a lot more of the former than of the latter because "cracking down" tends to involve the application of law (and a law and order discourse), whereas "facilitating" tends to be a matter of bureaucratic resources. Both the impetus to crack down and the desire to attract immigrants are related to the influence of globalizing forces.

We are all familiar with elements of the stock story of globalization. Globalization is about economic integration and communication technologies; more than a trillion dollars turned over each day on global currency markets; ${ }^{50}$ the McDonald's on Tiannamen square; the new wireless era in communications; and the production of Nike shoes in Vietnam. Globalization is also about the conceptual shifts that accompany these changes - the forces that have economic or communications effects also affect the way in which we envision the world and our place in it. Our capacity to imagine the world, including our perceptions of international borders and of nations as entities and the way that imagination seeps into our retelling of the world, are also part of globalization.

The place of both migration and migration laws in the story of globalization is harder to discern. ${ }^{51}$ The intuitive sense that more and more people are on the move than ever before is difficult to prove, especially with the vastly-increasing world population and the distinction between travel and migration. In the largest study to date of an array of phenomena associated with globalization, David Held and three co-authors concluded that current levels of migration are approaching the most extensive in the world and may, if present trends continue, surpass previous level of migration in both "intensity" and "extensity." ${ }^{52}$ They drew these conclusions in 1999. There has not been enough time for the trends visible then to have been either overtaken or reversed, particularly as the principal nations with organized migration programs have more or less stayed the policy course over that time frame, with

50 In hundred dollar bills, Anthony Giddens tells us that this forms a stack of money 120 miles high 20 times higher than Mount Everest. Impressive though that image is, Giddens used it in 2000, an eternity ago by globalization's clock (Anthony Giddens, Runaway World: How Globalization is Reshaping Our Lives (New York: Routledge, 2000) at 27-28).

\$I discuss this in greater detail in "Illegal Migration and Sovereignty in Theories of Globalization" in Catherine Dauvergne, ed., Jurisprudence for an Interconnected Globe (Burlington, VT: Ashgate Press, 2003) 1 .

:2 David Held et al, Global Transformations: Politics, Economics and Culture (Cambridge: Polity Press, 1999) at c. 6. They also considered "velocity" and "impact on host and home societies." 
some slowing of refugee flows evident in response to post-September 11 policies. ${ }^{53}$ It is thus at least provisionally safe to conclude that the place of migration in the globalization story is unclear.

Much of the theoretical debate about globalization centres on the role of the nation state. In this debate, the positions range from those who assert that the nation state is already irrelevant to those who claim, on the contrary, that nation states are more important than ever in a globalized world. ${ }^{54}$ The key variable in the argument is the degree of control - or better, influence - that nation states have in particular policy areas. The place of migration in this analysis is vital: control over visas, passports, work permits, and national membership are held up as the examples of the nation state's continuing prowess. ${ }^{55}$ Some analysts have even moved to defining sovereignty principally in terms of control over the movement of people over borders. ${ }^{56}$ When these arguments are translated into legal discourses, all of the evidence mustered in support of the continuing relevance of the nation state is found in the texts of immigration laws.

Given threats to the relevance and vitality of the nation state, the importance of immigration laws is reflected in a series of changes in the laws of powerful nations aimed at "cracking down" on "illegal" migration and at facilitating the flow of the world's most desirable migrants - with desirability defined in globalization's terms. Paradoxical effects are common in theorization of globalization. ${ }^{57}$ The impetus towards "crack down" demonstrates nations asserting their sovereignty and control. As globalizing forces challenge nations' capacities to set their own policies and limits, controlling migration marks their strength in a domain immune from permissible international incursions. Labelling part of the nation's population "illegal" ensures that the clear us-them distinction at the heart of immigration law is maintained, even if the physical border of the nation is breached. Attempting to attract the best and the brightest migrants also reflects globalization's agenda

53 This is demonstrated in the 2003 World Refugee Survey, published by the U.S. Committee for Refugees and available online: U.S. Committee for Refugees <www.refugees.org/WRS2003.cfm.htm>. In considering the impact of refugee flows, it is important to note that in the United States. Canada, and Australia - all new nations of immigration - refugee flows make up a distant third category in annual migration intakes behind economic migration and family reunion migration.

Those arguing that the state is already in marked decline include: Ohmae Kenichi, End of the Nation State: The Rise of Regional Economies (New York: Free Press, 1995); and Neil MacCormick, "Beyond the Sovereign State" (1993) 56 Mod. L. Rev. I. On the other side of the argument are Linda Weiss, The Myth of the Powerless State: Governing the Economy in a Global Era (Cambridge: Polity Press, 1998) and John G. Ruggie, "Territoriality and Beyond: Problematizing modernity in international relations" (1993) 47 International Organization 139. Others occupy a middle ground: see Kanishka Jayasuriya, "Globalisation, Law and the Transformation of Sovereignty: The Emergence of Global Regulatory Governance" (1999) 6 Ind. J. Global Legal Stud. 425: and Paul Hirst, \& Grahame Thompson, Globalization in Question, 2d ed. (Cambridge: Polity Press, 1999). These are the vital elements in Hirst and Thompson's analysis, supra note 54 at c. 8.

See for example Kim Rubenstein, "Citizenship in a Borderless World" in Anthony Anghie \& Garry Sturgess, eds., Legal Visions of the 21st Century: Essays in Honour of Judge Christopher Weeramantry (Boston: Kluwer Law International, 1998). Christian Joppke includes control over admission and expulsion as one of the "core prerogatives" of states in Christian Joppke, "Why Liberal States Accept Unwanted Immigration" (1998) 50 World Politics 266: Saskia Sassen's analysis is similar, in Losing Control?: Sovereignty in an Age of Globalization (New' York: Columbia University Press, 1996). See Mark Findlay, "Crime, Terror and Transitional Cultures in a Contracting Globe" in Dauvergnc. supra note 51,231 at 231 . 
because these migrants are viewed as globally-mobile. Those who are currently recruited in this way reflect new contours of privilege for globalizing times. The fact that nations view themselves as being in competition for these migrants contributes to the shrinking of the globe $^{58}$ and the convergence of migration provisions. The most significant changes contained in the IRPA correspond to these markers of globalization: the IRPA "cracks down" in a wide variety of ways and it alters recruitment mechanisms for the most skilled.

The crack down phenomenon is truly widespread. In 1996, the United States introduced its Illegal Immigration Reform and Immigrant Responsibility Act of $1996^{59}$ focusing on measures such as document fraud, people-smuggling, and a ratcheting up of employer sanctions for those who employ extra-legal workers. The 1999 British Immigration and Asylum $A c t^{60}$ targeted unfounded asylum applications, fast-tracking "out" of the asylum system but not into it, reducing rights for asylum-seekers and new identity controls. In early 2003, the United Kingdom implemented significant cuts to asylum-seeker assistance, ostensibly aimed at those making false claims. ${ }^{61}$ Germany changed the form of its constitutional right to seek asylum in 1993 and in 1998 it introduced new law reducing benefits for asylum-seekers. ${ }^{62}$ France has reduced asylum-seeker benefits within the past decade. ${ }^{63}$ Since 1999 Australia has removed the possibility of permanent status from some refugees, ${ }^{64}$ has declared some of its own territory to be "beyond its borders" for the purpose of asylum claims, ${ }^{65}$ and introduced into its legislation a comprehensive privative clause ${ }^{66}-$ in total, amending its legislation several times in each of the past three years. The European Union (EU) is currently working on developing a common policy on illegal immigration to give effect to the Treaty of Amsterdam commitments in this direction. ${ }^{67}$ That this phenomenon is widespread rather than truly global is typical of globalization. Globalization is marked by uneven penetration, which in turn, reflects privilege and power. Wealthy nations are capable of cracking down on illegal migration as an attack on their sovereignty. The

"Outward Bound" (2002) 364:8292 The Economist 29.

Pub. L. 104-208, 110 Stat. 3009 [IIRIRA].

(U.K.), 1999, c. 33.

Nationality, Immigration and Asylum Act 2002, supra note 47 at s. 55. This provision was the subject of challenge in Q.v. Secretary of State for the Home Department, [2003] E.W.J. No. 718 (H.C.) and $Q, R$ (on the application of) $v$. Secretary of State for the Home Department, [2003] E.W.C.A. Civ 364. While the court required more procedural protections for applicants, the core of the provision was not defeated.

Worldwide Refugee Information, Country Report: Germany, online: U.S. Committee for Refugees $<$ www.refugees.org/world/countryrpt/europe/1999/germany.htm>.

Worldwide Refugee Information, Country Report: France, online: U.S. Committee for Refugees $<$ www.refugees.org/world/countryrpt/europe/1999/france.htm>.

Temporary visa status for refugees was introduced with Visa Subclass 785.

Migration Amendment (Excision from Migration Zone) Act, 2001 (Cth.).

Migration Legislation Amendment Act, (No. 1) 2001, (Cth.). In February 2003 the Australian High Court ruled that this clause would only function to protected errors within jurisdiction, but left the clause intact (Plaintiff SI57/2002 v. Commonwealth of Australia, [2003] HCA 2). This leaves room for the government to amend its legislation to protect more decisions from the complex jurisdictional error doctrine.

See European Commission, Commission Communication On The Development Of A Common Policy On Illegal Immigration, Smuggling And Trafficking Of Human Beings, External Borders And The Return Of Illegal Residents, 3 June 2003, online: Europa <europa.eu.int/comm/press_room/press packs/immigration/pp_immigration_en.htm>. 
meaning of sovereignty itself is altered in the case of poorer nations, which are unable to enforce crack down provisions. ${ }^{68}$

Among the wealthy countries of immigration - "crack down" is at the top of the agenda. Whether there is actually more illegal migration to "crack down on" is, again, a harder question to answer. Illegal migration by definition is often undetected, and until recently fewer resources were devoted worldwide to attempting to detect it. Detecting and cracking down increase the prevalence of illegal migration by those actions alone, even if the raw numbers are not changed. What is certain, however, is that globalization has altered both perceptions and realities of illegal migration. We can now read newspaper stories of unauthorized arrivals in Europe, Australia and Canada all within the same week. Our technologies and our growing interest in a shrunken globe create the sense that illegal immigration is happening everywhere all the time. The technologies of globalization fuel illegal migration from the "other" side as well: the people-smuggling industry is at the forefront of the wireless era. The perception of a smaller globe makes flight from one's circumstances easier to imagine and the distance from home easier to cross. Talk of illegal migration is more prevalent than ever under conditions of globalization, reaching the dimensions of global moral panic. ${ }^{69}$

The IRPA cracks down in various ways. First, it broadens criminal inadmissibility ${ }^{70}$ and second, it removes rights from those in the most serious criminal inadmissibility categories. ${ }^{71}$ Third, it introduces new penalties for trafficking and smuggling ${ }^{72}$ and fourth, it "streamlines" the secretive national security certificate procedures. ${ }^{73}$ There is a certain appeal to each of these groups of provisions - they are all aimed at ensuring that people who commit the worst of crimes are not welcome in Canada and that they can and will be asked to leave. Crack down generally garners a high degree of public support, and public opposition to these measures has come from a predictably "activist" sector of the Canadian population. There is, however, a marked Draconian tone to these measures. The ideological rationale for the criminal law - designed to protect the individual from the power of the state - is absent here. Substituted instead are lower standards of proof, fewer rights protections, and broad, amorphous definitions. ${ }^{74}$ The message conveyed by "crack down" measures, in Canada as around the world, is that there is one standard for members, another for outsiders.

The IRPA was passed into law after September 11, 2001. Despite this, these measures were largely in place in draft form before that date, reflecting a worldwide trend. The events of September 11 generated some support for Draconian immigration measures, but their

Peter Fitzpatrick discusses this hierarchy of "nationness" in Modernism and the Grounds of Law, (Cambridge: Cambridge University Press, 2001) at 111-45.

(i) I adapt this phrase from Stuart Hall et al., Policing the Crisis: Mugging the State and Law and Order (London and Basingstoke: Macmillan, 1978).

Supra note 1 at ss. 33-37.

Ibid., s. 64.

Ibid., ss. 117-21.

Ibid., ss. 76-87, Division 9, "Protection of Information."

In Suresh v. Canada (Minister of Citizenship and Immigration), [2002] 1 S.C.R. 3 [Suresh], the Supreme Court of Canada found that the term "terrorism" in the former Immigration Act was not unconstitutionally vague. 
greatest effects have been felt in other areas of the law. ${ }^{75}$ Instead, in the post-September 11 world, the Canadian government is more inclined to use its discretionary power to define the national interest in the immigration context in ways that put state interests before individual rights. A recent spate of concern about the use of the national security certificate procedure seems to be one result of this. ${ }^{76}$ September 11 did not alter the trajectory of immigration law's crack down, but it has hastened its pace and smoothed its progress. It has ushered in a public tolerance for discretionary government actions aimed at "outsiders." Immigration laws, including the IRPA, its predecessor, ${ }^{77}$ and others around the world, provide a framework in which discretion in the name of national security is accommodated. In these present, dangerous times, this discretion is more likely to be used and its use is less likely to be questioned. In this way, the events of September 11 contribute to the global "crack down" atmosphere, even if changes in immigration laws are not their direct result. ${ }^{78}$ As such, the events of September 11 must be understood as a symptom rather than a harbinger of globalizing forces.

The other significant changes in the new IRPA - shifting the basic principles of skilled worker admission - also reflect a globalized context. There is an increasing rhetoric of worldwide competition for the "best and the brightest." This competition is particularly intense in those industries that service globalization, such as information technology, high finance, and the knowledge workers of at least some parts of the academy. The changes in recruitment of both permanent and temporary skilled workers are aimed at enhancing Canada's competitive advantages in these areas. The principal difference in this category has been to alter the "points system" to emphasize the type of training said to best suit the "new" economy ${ }^{79}$ Rather than attempting to attract individuals for particular jobs or job sectors, Canada's system has been retooled to attract those who will be able to move through different types of jobs over the course of their lifetime in keeping with the contemporary vision of the successful worker. While points are still awarded for having a job offer in hand, most recruiting to meet specific need is now in the temporary sector, or outside the immigration realm altogether.$^{80}$ Foreign students who have trained in Canada are now more welcome to stay, and the requirements for temporary work permits have been clarified. ${ }^{81}$

For example in Canada's new Anti-Terrorism Act, S.C. 2001, c. 41 and the new Privacy Act, R.S. 1985, c. P-21.

See Canadian Council for Refugees, “'Security Certificates' an insult to Canadians” (press release) (30 May 2003); and Tu Thanh Ha, "Montreal Man Suspected Of Terror Links Arrested" The Globe and Mail (22 May 2003) Al.

Immigration Act, supra note 2.

In the United States, some immigration provisions have changed in direct consequence of the September 11 attacks. Most prominent among these, from a Canadian vantage point, is the announcement of impending universal entry and exit controls. See Paul Koring, "Country Of Origin Key To New U.S. Visa Plan" The Globe and Mail (22 May 2003) A4.

The points system as applied to each category of economic migrant is set out in Part 6 of the IRPR, supra note 6.

Under the North American Free Trade Agreement [NAFTA], many service workers can move through North America without passing through the immigration net. Saskia Sassen asserts that this and similar arrangements in other trade agreements constitutes "labour circulation systems" which have been "uncoupled from any notion of migration, even though they involve a version of temporary labour migration and they are in good part under the oversight of entities that are quite autonomous from government" (supra note 56 at 88 ).

IRPR, supra note 6, Part 9. 
This recruitment of skilled workers is symbolically important to Canada's immigration law, particularly given the government's shift in the mid-1990s making "economic migration" (those admitted because of their economic contribution) a higher priority than family reunion migration. ${ }^{82}$ In the economic category, the skilled worker group is highlighted in government rhetoric, and in broader public calls for changes to Canadian immigration policy. ${ }^{83}$ This is probably, in part, because the skilled worker migrant conforms most closely to the traditional migration mythology of nation building - of hardworking folk coming to the ends of the earth to make their fortune and establish this new land $\mathrm{d}^{84}$ and because, unlike other economic migrants, this part of the program has not been subject to serious criticism recently. It is also because, in the face of recent concern about an alleged decline in labour market performance of newcomers, the government is keen to "prove" the economic value of migration. ${ }^{85}$ Skilled workers also make up the majority of the economic migration category. The other categories are investor migration, entrepreneurial migration, and live-in caregivers. ${ }^{86}$ These other categories were targeted to make up roughly 12 percent of total economic admissions in $2002 .{ }^{87}$ Statistics in the economic migration category also reflect the fact that these migrants (aside from live-in caregivers) are permitted to bring their families with them.

The changes to immigration laws reflect the globalized objective of recruiting better, brighter, and faster candidates. It is unclear whether they will achieve these goals. There are three issues to consider in this regard. First, the legislation does not determine the "pass mark" on the points test, meaning that under IRPA it could be harder or easier for those with skills to enter Canada. ${ }^{88}$ Ensuring that the skills test is more precise is one of the government's stated objectives and is coherent with a globalizing agenda. It does lead to the possibility, therefore, that it is harder for skilled people to enter Canada. A second pressing issue is that admittance as a skilled professional does not guarantee recognition by the relevant non-governmental accreditation body. This is beyond the reach of the legislation, and is even beyond the public sector. It is, however, a serious problem in Canada and one that the government should take more substantial steps to address. Finally, one of the principles of globalization is that control over economic flows are increasingly beyond the reach of national governmental policy. Immigration law provides a paradigmatic illustration

*2 This change took effect in 1995

8.3 For example, Diane Francis, Immigration: The Economic Case (Toronto: Key Porter Books, 2002) [Immigration]; Daniel Stoffman, Who Gets In? What's Wrong with Canada's Immigration System and How to Fix It (Toronto: Macfarlane Walter \& Ross, 2002); and Martin Collacott, Canada's Immigration Policy: The Need for Major Reform (Vancouver: The Fraser Institute, 2002). It is specifically with this lament, updated to the 1960s, that Diane Francis opens her book, Immigration, ibid.

*5 See Peter Li, Destination Canada: Immigration Debates and Issues (Toronto: Oxford University Press, 2003) at c. 5, "Economic Benefit of Immigration" for an analysis suggesting that there is no such decline.

*6. Each of these categories is defined in Part 6 of the IRPR, supra note 6. Investors must have a minimum net worth of $\$ 800,000$ and entrepreneurs must have a minimum net worth of $\$ 300,000$. For the first two of these categories, the points system is adapted to allow investment in Canada to count for a considerable portion of the admissibility measure. For live-in caregivers, the economic contribution is in an area where chronic labour shortages and high skill levels do not coincide.

87 As calculated from Canada, Department of Citizenship and Immigration, The Immigration Plan for 2002, online: Citizenship and Immigration Canada <wivw.cic.gc.ca/english/pub/anrept $01 . h t m l>$.

sx It is certainly the case that for some people it will be harder to enter than before, which is why class litigation is being pursued with the aim of having a large group of applicants processed under the old rules. See Dragan v. Canada (Minister of Citizenship and Immigration) (2003), F.T.R. 272 (T.D.). 
of this principle. The United States has no trouble attracting skilled immigrants, despite being the only major "nation of immigration" where family reunion intake still massively outstrips economic class migration, and despite having arguably the most cumbersome immigration bureaucracy in the world. The size of the United States economy itself attracts migrants, authorized or not. Extensive retooling of immigration laws cannot alter the magnetic effect of economy size and the American dollar.

For economic migration, as with illegal migration, Canada's IRPA reflects global convergence of policy. Around the world, prosperous nations are shifting immigration laws in the same two directions. Whether it is free movement within the European Union, the nonimmigration of service workers under NAFTA, the easing of Australian recruitment rules, ${ }^{89}$ or the mass exodus of professionals from Albania, ${ }^{90}$ an era of globalization has ushered in a new variety of mobility based on skill. Typically for globalization's stock story, it matters little what direction the laws of non-prosperous nations take. It is either the case that few want to go there or that those nations lack capacity to enforce any provisions that they might legislate. Wealthy nations are the authors of globalization's story. ${ }^{91}$ In an earlier era, the hardworking migrant "types" were expected to sacrifice in the New World to make a better life for their children. This myth has ended. Now the fact that migrants are toiling through the night cleaning office towers or driving taxis is seen as a system failure. Those not qualified or permitted immediate access to the middle class should, so the new myth goes, stay home. The changes in the new IRPA that aim to attract the world's best are both a "new" element for Canadian law and a reflection of this globalized trend.

\section{THE RESILIENCE OF IMMIGRATION LAW}

Overall, the picture of Canada's new immigration and refugee protection legislation is one of resilience. Despite the extensive efforts at consultation and the 26 years since the last major rewriting of the rules, most of the changes either legislate the discretionary status quo or install halfway measures. The key features of Canada's immigration law remain in place: a tripartite division into economic, family, and humanitarian migration (and an insistence on treating refugee admissions as part of this administrative regime) ${ }^{92}$ the use of a "points system" as a decision-making mechanism; and the central role of the IRB. Accounting for this resilience is vital, and it also contributes to understanding why it is that global trends outside the nation - rather than activists, politicians, and bureaucrats within the nation seem to have had the most influence on the shape of the new law.

See remarks by Hon. Phillip Ruddock, Australian Minister for Immigration and Indigenous Affairs, Press Conference on the Migration Program for 2003-04, (31 March 2003), online: Minister for Immigration and Multicultural and Indigenous Affairs <www.minister.immi.gov.au/media_releases/ ruddock_media03/r03018.htm>.

"The View from Afar" (2002) 365:8297 The Economist 11 (supplement at 50-51).

Even relatively prosperous New Zealand is facing an overall loss of population because of migration over the past decade; the small scale of its economy makes it hard to compete in the "best and brightest" stake. On the crack down side, the majority of the world's potential refugees have flowed over borders in Africa and Asia, not in the Western states where the contemporary "crisis of refugee law" is situated. This structure is similar in all prosperous nations with organized migration programs. Germany and Israel add to this structure a category for those who are members of a community which is defined in ways other than according to political borders. 
This overwhelming resilience is linked to the characteristics of immigration laws of liberal communities. Immigration law inscribes the border of the national community. In settler societies such as Canada, the United States, Australia, and New Zealand, this is historically observable in a straightforward way. The permissions and prohibitions surrounding immigration over the past two centuries have shaped the present populations of these countries. Then, as now, who becomes part of the Canadian community is determined at first instance by immigration law. Who can enter the nation, and on what conditions, is inscribed in the text of our immigration law. We define ourselves through our immigration law, more than through any other legal text, including our citizenship law and our constitution. With this law we bring into existence the group for whom the constitution is then interpreted and infused with meaning, as well as the eligibility group of potential new citizens.

In order for the nation to exist, for there to be a community, there must be a boundary. There is an on-going debate in liberal theory about whether the border to the liberal community should be closed or open, but there is no question that a boundary must exist. ${ }^{93}$ Although the border "exists" as an image on a map, what makes it meaningful are the legal texts that protect and defend it. Immigration law is not the only law involved here, but it is the key one when people rather than things or money are crossing borders. One reason why the concept of "national interest" is so vital to immigration law is because of the role this law plays in constituting the nation. A principal function of immigration law is to establish the conditions under which there can be a national interest.

National interest changes. This basic fact accounts for much of the structure of our immigration law and for its resilience. Immigration law frames national interest, yet national interest is almost infinitely variable. The result is an immigration law that acts as a framework, a container into which the national interest of the day can be contained and given the authority of law. The things which matter most about immigration law - how many get in and when - are not part of the law, nor even part of the regulations, but are decided on an on-going basis as a matter of policy and politics. This law does not set a priority between economic or family migrants, does not set a number ${ }^{94}$ in any category, does not determine what a pass mark is in any pool, and has enough objectives that any conceivable change of policy will meet at least some. This is the subtle trick of immigration law. A border cannot be infinitely variable or it lacks meaning. Immigration law sets up the balancing mechanism that allows the national boundary to retain the veneer of solidity provided by the law and its

9.3 I discuss the parameters of this debate in "Amorality and Humanitarianism," supra note 28. Michael Walzer's Spheres of Justice: A Defense of Pluralism and Equality (New York: Basic Books, 1983) is the seminal work on the closed borders side of the argument. Donald Galloway makes this argument in the Canadian context in "Liberalism, Globalism and Immigration" (1993) 18 Queen's L.J. 266; and "Strangers and Members: Equality in an Immigration Setting" (1994) 7 Can. L.J. \& Jur. 149. Joseph Carens outlines the open borders position in "Who Belongs? Theoretical and Legal Questions About Birthright Citizenship in the United States" (1987) 37 U.T.L.J. 413; "Aliens and Citizens: The Case for Open Borders" (1987) 49 The Review of Politics 251; "Membership and Morality: Admission to Citizenship in Liberal Democratic States" in Brubaker W.R., ed., Immigration and the Politics of Citizenship in Europe and North America (Lanham: University Press of America, 1989); "Refugees and the Limits of Obligation" (1992) 6 Public Affairs Quarterly 31; and "Open Borders and Liberal Limits: A Response to Isbister" (2000) 34 International Migration Review 636.

94 In contrast, American immigration law uses a legislated formula to produce an annual limit. American immigration law also constitutes the border of the nation, but does so with different specifics. 
rule of law ideology, while at the same time providing a flexible matrix that allows the boundary to vary unceasingly. The resilience of the basic structure of our immigration law draws partially from its role as the national boundary. As the law was already structured to accommodate considerable change, and the core questions of immigration politics are not settled in the law, there were few reasons to make considerable changes.

The second factor in the resilience of Canadian immigration law is also accounted for by the place of the law in the liberal nation. In liberal communities there is no consensus about the central questions of immigration, and nowhere to turn to seek that consensus. ${ }^{95}$ These central questions that the law does not answer do not have "right answers" in liberal terms. The provisional answer for any community at any point in time is defined by national interest and thus is a matter of public debate, of democratic politics. While for individuals in the community immigration may have a moral dimension, for the broader liberal community there is no moral authority available to settle the debate. ${ }^{96}$ Canadian immigration law has already addressed the principal questions for which liberal consensus provides an answer racial discrimination has been removed from the face of the law; humanitarianism has been inscribed within it. The Canadian Charter of Rights and Freedoms ${ }^{97}$ functions as a backstop in these areas. ${ }^{98}$ The Charter will not tell us how many must be admitted, when, and from where; thus, we must make these decisions on a democratic basis. Democracy is slow and incremental. It is well-suited to a framework law that is resistant to change because it contains little of the substance of the debate. Immigration law, in turn, is poorly-suited to significant change through democratic processes because the majority of those to whom the law will be applied are "outsiders"; they have no vote and no voice. Democracy itself aids in ensuring that the law is linked to narrowly-defined national self-interest. Given these factors, understanding the shape of our law involves looking to the politics of immigration, and considering how those politics are shaped in the era of globalization.

\section{CONCLUSIONS: IMMIGRATION POLITICS AND ITS LAW}

Immigration is almost constantly in the press. In addition to the inevitable coverage of high-profile immigration events such as the intermittent arrival of asylum-seekers in boats, there has also been considerable coverage of successive rounds of policy debate and coverage of a series of high-profile immigration policy critics - Martin Collacott, Diane Francis and Daniel Stoffman are among the most recent. ${ }^{99}$ This coverage reflects the persistent lack of consensus on the key questions of immigration and, in the absence of agreement, it is always possible to unearth dissension to report. As the politics of immigration injects crucial content into a framework of law, this on-going public discourse is relevant to

This is a result of the debate discussed in supra note 93.1 also make this argument fully in "Beyond Justice: The Consequences of Liberalism for Immigration Law" (1997) 10 Can. J.L. \& Jur. 323. Donald Galloway makes the point about individual moral duties and immigration well in "Liberalism, Globalism, and Immigration," supra note 93.

"* As is evident in cases like Baker v. Canada (Minister of Citizenship and Immigration), [1999] 2 S.C.R. 817; Suresh, supra note 74; Chiarelli v. Canada (Minister of Citizenship and Immigration), [1992] I S.C.R. 711; and Ahani v. Canada (Minister of Citizenship and Immigration), [2002] I S.C.R 72. 
understanding both the resilience of the form of the law and the content that will be injected into the legal framework.

Many have argued, Collacott, Francis and Stoffman among them, that immigration policy, and thus law, must be harnessed to some economic goal. If there were a truly broad consensus on this point, a simple prescription would seem to follow: find an economic model that is reliable, select a goal, and then pursue it. It would be more complicated than this, of course, but a prescription of this ilk would be considerably easier to manage than the 25 objectives of the present legislation. The position advanced by these three writers is that national interest, the illusive touchstone of immigration law, ought to be defined in solely economic terms. Even assuming that all concerned could agree about what those economic terms might be, we, as a national community, strongly resist thinking about immigration in solely economic terms. The failure to separate immigration law from refugee law (and its concomitant international legal obligations) reflects this, as do the overlapping and contradictory objectives of the new legislation. It is clearly the case that for some, admitting others to permanently live in our community is not only about the health of our economy. Sometimes, it is about our culture or our humanity. Given that we use immigration law to erect the boundary of our community where the national interest dictates it ought to be, this debate must somehow be encapsulated in the law.

This observation is borne out historically. There are no halcyon days of immigration law, where economic interests determined admittance and the result was prosperity for all. Our immigration history and mythology is instead marked by racist exclusions, by grand gestures of humanitarianism, by political compromise, and by discretion. That immigrants were more easily absorbed into the economy at some points in time than others tells us more about the overall robustness of that economy, and about our techniques of measurement, than about immigration itself. And it tells us very little about immigration law, which is a lens that refracts the political debate rather than a fixed outcome of it. Most of what occupies the debate (the numbers, the relative priority between types of immigrants) is not in the law, so that the law and the public discourse run on parallel tracks sometimes, but do not often intersect. This may be why Stoffman writes that Canadians have not been adequately consulted about changes in the law, despite the extensive consultations of the past decade. The nature of public debate about immigration - here and elsewhere - confirms the place of immigration law in the mythology of globalization: that is, immigration remains closely connected to the nation - its interests and its values - and controlling it is an important marker of the continued importance of the nation state facing global challenges.

The consequence of focusing public and political debate on the nation is that we risk overlooking the global patterns and relevance of immigration - that we miss the opportunity to think about vital issues like culture or justice from anything other than a national point of view. Critically, we miss the point that the nature of the nation is changing, regardless of whether one views it as diminishing or not. Similarly, it is backward-looking to focus on economic well-being as something that can be harnessed and determined at a national level, despite all of the other indicators that suggest that in global times, economic control is the first to slip beyond the grasp of national governments. In the contemporary global era, though immigration laws will certainly be made by national governments, no policy direction, be it of recruitment or crack down, can be implemented or debated without regard to what is 
happening beyond the increasingly porous border. The law is focused on the national interest at a time when truly "national" interest is increasingly difficult to define or to attempt to achieve, thus robbing public debate of its points of reference. International patterns of immigration laws are implicated in globalization's record of widening the gap between rich and poor, as those with training and experience are sought-after by the wealthiest nations. ${ }^{100}$ It might not be in our national interest that global inequities increase - but that question is not presently on the agenda.

Canada's public and political discourse of immigration is at risk of losing touch with the issues that will shape the future of immigration to, and emigration from, this country. The resolute focus on a narrowly-confined national interest is nostalgic. The twentieth century was the high point of truly national immigration laws, and it is a twentieth century politics that continues to dominate public debate. Prior to that time, immigration was much more open. ${ }^{101}$ At the outset of the twenty-first century, the capacity of nations to harness immigration to any particular goal is being eroded by the changing shape of the world economy, the increasing potency of international legal regimes, and the convergence of immigration regimes among those nations which are sought after destinations. The most significant changes of Canada's new legislation are those reflecting these globalized realities. But the law must be given its substance by immigration politics. To remain relevant, these politics must take account of the global context of our immigration law. Globalization has brought increased pressure to the linkage between immigration law and national selfdefinition. A politics that ignores global dynamics will be unable to meaningfully contribute to the content of the law. The IRPA reflects compromise between global and national forces but, because it is a framework, its project is unfinished. If Canadian public and political discourses about immigration continue to look only inward, the opportunity to develop a national understanding of the global context of the law and to use that understanding to give content to the law will be lost. 